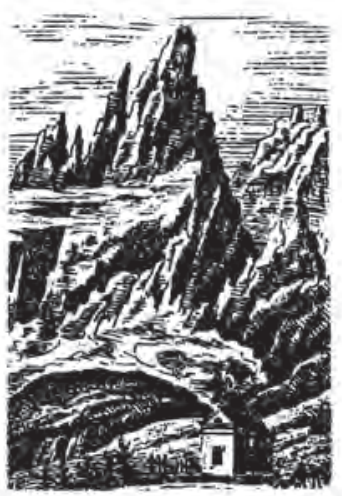

\author{
Jolanta Ługowska \\ ORCID: 0000-0001-9071-9139 \\ Uniwersytet Wrocławski \\ jolanta.lugowska@uwr.edu.pl
}

https://doi.org/10.19195/2084-4107.13.16

\title{
Róża bez kolców Zofii Urbanowskiej — między "reklamą" a idealizacją Tatr
}

Słowa-klucze: Tatry, literatura dla młodego odbiorcy, idealizacja, reklama

Keywords: Tatras, literature for young readers, idealisation, publicity

\section{Zofia Urbanowska’s Róża bez kolców - between "publicity" for and idealisation of the Tatras}

\section{Summary}

Zofia Urbanowska's Róża bez kolców [Rose Without Thorns] planned and written by the author as a "fictionalised encyclopaedia of the Tatras" is a valuable source of information, which had its roots both in the Urbanowska's own experiences associated with her visits to Zakopane filled with field studies, as it were, and meticulous note-taking, and in the literature on the subject, particularly Stanisław Witkiewicz's Na przełęczy. It is possible to distinguish two levels of meanings in the image of the Tatras created by the author, meanings highlighted primarily in the dialogues of the protagonists, both fictional, belonging to the world presented in Róża bez kolców, and those modelled on real people (Witkiewicz, Matlakowski and others). The first of these levels of meanings is associated with an idea - journalistic in its origin — of popularising the Tatras and highland folklore, an idea defined as a "civic duty" leading, as it turns out in Urbanowska's novel, to a kind of publicity for the 
(highest and most beautiful) Polish mountains. The second level is associated with a unique model - firmly established in the literary tradition — of "reading" the Tatra landscape with the help of the language of culture, for example by looking for similarities between natural objects and works of art, or in the writer's attempts to interpret the symbolic meanings of natural images.

\section{„Trawy tu są zieleńsze, chabry modrzejsze, jaskry żółciejsze..."1}

Róża bez kolców Zofii Urbanowskiej w chwili publikacji pierwszego wydania książki (1903 rok) stała się, jak powiada Jacek Kolbuszewski, „rzeczywistą encyklopedią tatrzańską, informującą o literaturze tatrzańskiej, o topografii, florze, faunie gór”, spełniając zadanie, jakie — zgodnie z opinią badacza — „wychowana w duchu pozytywistycznej ideologii autorka zamierzała jej nadać"2. Potwierdzeniem sformułowanej tezy jest na pewno charakterystyczna, godna uwagi literaturoznawców, autotematyczna refleksja pisarki, zawarta w jej liście do Stanisława Witkiewicza, w którym - poza prośbą o lekturę i ewentualne korekty przesłanych mu gotowych części przygotowywanego dzieła ${ }^{3}$ — dzieli się z adresatem własnymi przemyśleniami i intencją towarzyszącą pracy nad książką:

Bardzo, bardzo byłabym wdzięczną Szanownemu Panu, gdyby Pan czytając moją pracę, zechciał ją opatrzyć swymi uwagami i dopomóc mi w tym, aby rzecz ta, której celem jest rozbudzenie w młodzieży ukochanie Tatr i zachęcenie jej do ich zwiedzania, była — o ile możności — dobrą i kompletną pod względem koniecznych informacji o tych górach, o ile ramy powieściowe na to pozwalają. Celem moim było, aby każdy, kto przeczyta tę książkę, dowiedział się nie tylko, jakie są w Tatrach minerały, zwierzęta i rośliny, ale jakie piosenki, jaki lud, jakie niegdyś były dzieje Podhala ${ }^{4}$.

Do realizacji podjętego zadania Urbanowska przygotowywała się długo i sumiennie. Jak przypomina w swym studium Maria Jazowska-Gomulska, od pierwszego swego pobytu w Zakopanem w 1882 roku Urbanowska zapisywała swoje obserwacje, gromadziła notatki, zbierała teksty ludowe (część z nich — pieśni z okolic Poronina i Zakopanego - przekazała Oskarowi Kolbergowi) a także publikowała na łamach „Kroniki Rodzinnej” korespondencje z Zakopanego, w których wyraża się znamienne przeświadczenie autorki o krajoznawczych i kul-

1 Z. Urbanowska, Róża bez kolców, Warszawa 1980, s. 280.

2 J. Kolbuszewski, Tatry w literaturze polskiej, cz. 1-2, Kraków 1982, s. 193.

3 Pierwodruk powieści Urbanowskiej ukazał się na łamach czasopisma dla młodzieży „Wieczory Rodzinne" w latach 1900-1901. Zob. M. Jazowska-Gomulska, Róża bez kolców. Dzieje wydawnicze powieści, „Annales Universitatis Paedagogicae Cracoviensis” 8, 2010, s. 142-155.

4 Zofia Urbanowska do Stanistawa Witkiewicza, list z dnia 15 czerwca 1901 roku, [w:] Listy o stylu zakopiańskim 1892-1912. Wokót Stanisława Witkiewicza, oprac. M. Jagiełło, Kraków 1979, s. 671. 
turowych wartościach Tatr — stąd wola ich popularyzacji, formułowana explicite zachęta do ich zwiedzania i poznawania.

Kto by pragnął to wszystko i więcej jeszcze poznać, niech tu przybywa co najczęściej, niech się zżyje z miejscowością, a nade wszystko zrozumie naturę tutejszego zakątka naszej ziemi, uroki jego ponętne i grozę przerażającą, na jej tle dzieje się bowiem tu wszystko. Na jej opisanie dokładne pióra poetów i pędzle malarzy nie okazały się dostateczne. Trzeba tu przebywać, umieć patrzeć i odczuwać 5 .

Wydaje się znaczące, że apel o tej samej treści — „Jedźcie i oglądajcie”6 — znajdzie się w ,absolutnym wygłosie” epilogu powieści Róża bez kolców, świadcząc o stabilności celów i założeń pisarki wiążących się z Tatrami, pojmowanymi (zgodnie z przytoczoną wcześniej quasi-definicją pisarki) jako skomplikowana, krajobrazowo-antropologiczna całość, na którą składają się góry, tatrzańska przyroda i mieszkający tu ludzie (,Sabała to też jedna z największych osobliwości tych gór"7), funkcjonująca niejako na styku natury i nasyconej wartościami kultury ${ }^{8}$.

W myśleniu Urbanowskiej o Tatrach zdają się obecne dwa porządki decydujące o kształcie świata przedstawionego Róży bez kolców. Pierwszy z nich, bardziej pragmatyczny i o genezie publicystycznej, wydaje się konsekwencją pojmowania przez pisarkę w kategoriach niemal „obywatelskiego obowiązku” zadania popularyzacji i de facto reklamowania zarówno samych Tatr, jak i najwybitniejszych, jak mówił Hoesick, „legendowych postaci zakopiańskich”, a wyrażającego się, na co zwróciła uwage Pola Kuleczka, w konstruowaniu sui generis wykładów „o zabarwieniu propagandowym"10, jak również w formułowanych explicite apelach i zachętach do określonych działań o charakterze turystycznym i krajoznawczym. Drugi natomiast, wpisany w określoną tradycję literacką (przede wszystkim w program i dokonania Stanisława Witkiewicza, z jego najsłynniejszym, inspirującym Urbanowską dziełem $N a$ przełęczy ${ }^{11}$ ), polega na wyrazistej waloryza-

${ }^{5}$ Cyt. za: M. Jazowska-Gomulska, Antropologiczna koncepcja kultury $w$ Róży bez kolców Zofii Urbanowskiej, [w:] eadem, Oswajanie z kulturą. W kręgu inspiracji folklorystycznych w literaturze dla dzieci i młodzieży, Kraków 2001, s. 67.

6 Z. Urbanowska, op. cit., s. 557.

7 Ibidem, s. 282.

8 Por. „Obecnie stan badań nad antropologią kultury, rosnąca jej ranga jako metody badawczej, pozwala i zjawiska literatury związanej z górami rozpatrywać jako ważny wycinek historii kultury. Systemy wartości przypisywane górom także przez pisarzy i artystów ujawniają godne uwagi prawidłowości w przemianie postaw wobec natury i świata" - M. Jazowska-Gomulska, Antropologiczna koncepcja..., s. 62.

9 Por. F. Hoesick, Legendowe postacie zakopiańskie. Chałubiński, ks. Stolarczyk, Sabała, Warszawa 1922.

10 P. Kuleczka, Tatry w literaturze polskiej dla dzieci i młodzieży do roku 1939, Zielona Góra 1994, s. 94.

11 Por. „Wiem, że Szanowny Pan góry te całym sercem ukochał, bo miłość gorąca tryska z każdej karty dzieła Jego Na przełęczy [...]. Z pięknej pracy Pańskiej dużo korzystałam” - Zofia Urbanowska do Stanisława Witkiewicza..., s. 671. 
cji (określanej często mianem idealizacji) zarówno poszczególnych elementów prezentowanego świata, jak i tego świata jako całości, a także na przypisywaniu mu nowych znaczeń, związanych z perspektywą i punktem widzenia podmiotu podróżnika i turysty, czasem, jak rzecz ma się w przypadku pierwszoplanowego protagonisty Róży bez kolców, baroneta Edwarda Warburtona, pielgrzyma. Oba te porządki współistnieją i uzupełniają się w kompozycji dzieła. Ze względów badawczo-analitycznych warto je jednak rozdzielić.

Kierując się doświadczeniem współczesnego użytkownika mediów, zarówno tych usytuowanych w „galaktyce Gutenberga”, jak i elektronicznych, nietrudno dostrzec i wyodrębnić w narracji Róży bez kolców wypowiedzi porównywalne do swoistej stylistyki folderu — druku informacyjno-reklamowego, zawierającego opisy uznanych za godne obejrzenia miejsc i obiektów. W tych fragmentach dzieła można się jednak dopatrzyć także podobieństwa do samych podstaw ,języka reklamy", odnoszącego się nie tylko do konkretnych produktów (w przypadku zastosowania wąskiego rozumienia pojęcia reklamy), lecz także do wszelkich idei i konkretnych działań, uznanych za wartościowe i godne upowszechnienia ${ }^{12}$. Celem komunikatu reklamowego jest przy tym przekonanie odbiorcy o potrzebie posiadania przez niego określonego przedmiotu bądź podjęcia konkretnego działania ${ }^{13}$, będącego konsekwencją przeświadczenia, że wskazany w przekazie reklamowym produkt jest lepszy od innych obecnych na rynku jego odpowiedników, ze względów formalno-prawnych zwanych zazwyczaj „zwykłymi”" ${ }^{14}$. W odróżnieniu jednak od twórców popularnych dziś (przede wszystkim w telewizji) reklam Urbanowska - korzystając ze swobody, jaką daje licentia poetica — odważnie zestawia i konfrontuje „reklamowane” przez siebie Tatry nie z (jakimikolwiek) „,innymi” górami, lecz z górami konkretnymi, będącymi często celem podróży współczesnych jej rodaków, a więc przede wszystkim z Alpami:

Tatry [...] są piękniejsze i bardziej malownicze od Alp, bo gdy tam przeważnie są skały pokryte śniegiem lub stoki roślinnością okryte, nasze Tatry nie tak wysokie, ale dziksze, przeważnie lasami porosłe, które tak w lecie, jak w zimie piękną im nadają zieloność ${ }^{15}$.

12 Por. w szerszym rozumieniu ,reklama obejmuje również wypowiedzi polityczne, społeczne i inne, promujące określone idee i sprawy" - E. Nowińska, Prawo reklamy, [w:] K. Janiszewska et al., Wiedza o reklamie. Od pomystu do efektu, Bielsko-Biała 2009, s. 327.

13 Por. „Komunikat reklamowy jest zorientowany teleologicznie i funkcjonalnie [...] jego celem jest, primo: rozpowszechnienie informacji o towarach, czyli komunikowanie komuś — czegoś - o czymś, secundo: przekonywanie, nakłanianie odbiorcy do przyjęcia określonego sądu, zachęcanie do podjęcia konkretnego (zasugerowanego przyjętym sądem) działania, czyli wywieranie realnego wpływu na odbiorcę przez perswazję" - P. Lewiński, Retoryka reklamy, Wrocław 1999, s. 23.

14 Jedną z funkcji reklamy jest ,ustalenie zalet przedmiotu reklamy w odniesieniu do innych produktów/firm bądź, jeśli reklama porównawcza jest zakazana, w relacji do niedookreślonego "zwykłego towaru«" - ibidem, s. 28.

15 Z. Urbanowska, op. cit., s. 63-64. 
Zgodnie z retoryką tego rodzaju komunikatów w powieści Urbanowskiej, w celu uwiarygodnienia formułowanych opinii, pojawiają się charakterystyczne wzmianki o „,autorytetach” je wspierających: podróżnikach, pisarzach, uczonych.

Tatry są taką osobliwością [...], że znawcy nie wiedzą, z jakimi je górami porównać. Słynny podróżnik i autor, Jerzy Brandes, zwiedziwszy wprzód Alpy szwajcarskie, tyrolskie i austriackie, Pireneje, Sierra Nevada, Sierra Morena i Guadarama, Apeniny, góry szkockie, skandynawskie i greckie, powiedział, gdy przed Tatrami stanął po raz pierwszy, że „takich gór nigdy nie widział $\mathrm{i}$ że podobnych nie tylko nie ma w Europie, ale chyba na całej ziemi"16.

Zachęta do zwiedzenia najwyższych (i najpiękniejszych!) gór Polski w tego rodzaju komunikatach jest przy tym „oczywistą” konsekwencją nie tylko krajobrazowych i estetycznych ich walorów. Apel ,jedźcie i oglądajcie” motywowany jest przecież także walorami klimatycznymi Zakopanego - miejscowości prezentowanej w powieści jako niewystarczająco jeszcze znany i spopularyzowany kurort:

Klimat tatrzański nawet dla osób dotkniętych chorobami dróg oddechowych wyższość ma nad alpejskim. [...] Na górach szwajcarskich podczas nocy, w lecie, bywa po kilka stopni mrozu, a w Tatrach zdarza się to chyba wyjątkowo, tam przeto więcej jest sposobności do zaziębienia się niż tutaj. Wobec takich warunków ciepłoty o ileż łagodniejszym jest klimat Tatr, o ile bezpieczniejsze podróżowanie po tych górach ${ }^{17}$.

Ze względu na wysoką zawartość ozonu powietrze tatrzańskie jest „czystości nadzwyczajnej" - utrzymuje jeden z protagonistów powieści o wykształceniu i kompetencjach przyrodniczych. „Badał je profesor Bujwid i nie znalazł w nim wielu bakterii chorobotwórczych. Dlatego, gdy w innych krajach ludzie chronią się do domu przed wilgocią z obawy zaziębienia, tutaj swobodnie używają spaceru” 18 . Warto podkreślić, że tego rodzaju „kryptoreklamy” są w strukturze narracyjnej powieści integralnymi replikami dialogowymi konkretnych bohaterów, wpisanymi w logikę fabularną utworu. Wiążą się one z profesjonalnymi zainteresowaniami i kompetencjami protagonistów. Wyjaśnienia dotyczące walorów klimatycznych Zakopanego pojawiają się więc nieprzypadkowo w dialogach Jakuba - z zawodu lekarza - z babunią Kasią, niepokojącą się o stan zdrowia chorowitej wnuczki, a także w rozmowach z antypatyczną „milady” Alicją, również poważnie zatroskaną z powodu zagrożenia, jakim surowy klimat tatrzański może być dla jej rozpieszczonego i hipochondrycznego syna, a ponadto, zgodnie z obowiązującą modą, preferującą ,włoskie klimaty”. Dzięki temu jawnie „,deklaratywne" wypowiedzi rezonerów zyskują swoiste uprawdopodobnienie właśnie

\footnotetext{
16 Ibidem, s. 63.

17 Ibidem, s. 34.

18 Ibidem, s. 62.
} 
jako kompetentne i dokładne odpowiedzi na umotywowane sytuacyjnie pytania i wątpliwości zgłaszane przez bohaterów niedysponujących wystarczającą wiedzą na temat rzeczywistości tatrzańskiej. Ich komunikacyjną, ale też swoiście edukacyjną skuteczność potwierdzają wypowiedzi w pełni już „przekonanych” do racji rezonera słuchaczy, czego przykładem może być patriotyczna ${ }^{19} \mathrm{w}$ wymowie replika wspomnianej babci Kasi:

dotąd tak zawsze bywało, że od nas wyjeżdżano za granicę i zachwycano się tam wszystkim, co tylko napotkano, a o naszym kraju było cicho, jakby makiem zasiał, jakby już u nas nic nie było godnego widzenia. A tutaj i cudzoziemcy zlatują się... No proszę! Chwała Bogu ${ }^{20}$.

Czasem pytania „nieświadomych” uczestników sytuacji dialogowych są swoistym pretekstem do „naukowych” wyjaśnień (imponująca pod tym względem wydaje się aktywność poznawcza nastoletniego Henryka, zasypującego interlokutorów pytaniami dotyczącymi obserwowanych obiektów i zjawisk), lecz także motywację do posłużenia się, powiedzieć można, gotowym sloganem reklamowym. Przedłużającą się z powodu kolejnych pytań chłopca rozmowę na temat mchów porastających góry kończy więc Jakub charakterystyczną konstatacją: „Jeśli chcesz poznać wszystkie mchy tatrzańskie, obejrzyj zbiór Chałubińskiego w muzeum" 21 . W chór autorytatywnych wypowiedzi „reklamujących” Tatry, formułowanych przez uczonych i artystów, wplata się niekiedy głos ,tubylców”, jak na przykład góralskiego przewodnika wiodącego swych podopiecznych przez Dolinę Jaworzynki do Hali Królowej: „U nas w Tatrach nic brzyćkiego nie ma”22. Swoista „kropka nad i” w całym łańcuchu pochwał turystycznych walorów i zachęt do zwiedzania Tatr postawiona zostaje w pełnym erudycyjnych rozważań dialogu, jaki wiodą zafascynowani Tatrami dwaj koryfeusze wiedzy i sztuki podhalańskiej - Stanisław Witkiewicz i Władysław Matlakowski: „Trzeba być gruboskórnym fizycznie i moralnie, żeby uroków tego kraju nie odczuwać"23.

Podjęta przez jednego z interlokutorów kwestia „odczuwania” uroków gór zdaje się przenosić interesującą autorkę problematykę tatrzańską na inny, wyższy poziom znaczeń, wiążący się ze swoistą sztuką czytania krajobrazu, zdolnością przekształcania fenomenu natury w „fakt kulturowy”. Góry, „,z natury” obojętne wobec ludzi, nieoferujące więc obserwatorowi (turyście, pielgrzymowi) „wprost”

${ }^{19}$ Na ten aspekt powieści dla młodzieży autorstwa Zofii Urbanowskiej zwraca uwagę Barbara Kosmowska: „Najbardziej znamienną opozycją [...] jest wyodrębniana przez pisarkę sfera polskości i obcości, wyraźnie zaznaczona w przestrzennych i czasowych ramach utworów za pomocą odpowiednio dobranych opisów przyrody. [...] Są one najczęściej stosowanym sposobem waloryzacji przestrzeni ojczyźnianej, przy jednoczesnej deprecjacji miejsc nieskładających na rodzimą przestrzeń" - eadem, Pomiędzy dzieciństwem a dorosłościa. O powieściopisarstwie Zofii Urbanowskiej, Słupsk 2003, s. 148.

20 Z. Urbanowska, op. cit., s. 63.

${ }^{21}$ Ibidem, s. 466.

22 Ibidem, s. 295.

23 Ibidem, s. 280. 
określonych wartości kulturowych, wymagają od niego, jak stwierdził Jacek Kolbuszewski, „odkrycia” i „ukonstytuowania ich w pojęcie”. To zatem dopiero „zajęcie przez człowieka jakiejś wobec nich postawy sprawia, że zaczynają być traktowane jako czynnik kulturotwórczy w wyniku poczynionych im swoistych »wmówień «"24. Jednym z takich „wmówien", egzemplifikowanych fabułą Róży bez kolców, wydaje się odkrywanie podobieństw między „obrazami natury” a wytworami artystycznej działalności człowieka, w wyniku czego odczucie naturalnego piękna gór i, co zdaje się ważne, zakomunikowanie tego odkrycia innym stają się możliwe jedynie przy wykorzystaniu języka kultury, używanego na przykład przy opisie dzieł sztuki i obiektów architektonicznych:

Uroczym zakątkiem jest Dolina Strążyska: nie tak przygniatająca ogromem i gotyckimi kształty kamiennych wieżyc jak Kościeliska, ale jednak wspaniała i pełna powabów. Jeżeli Kościeliska jest świątynią, której charakter najpełniej się maluje, gdy w niej, zamiast organów, pioruny grają hymny, a przyświecają błyskawice - to Strążyska kościołem, w którym ptaszki i pastuszkowie do mszy śpiewają. [...] Kościeliska posiada olbrzymią nawę, wyniosłe wieże i liczne po bokach kaplice, ale nie posiada chrzcielnicy tak wspaniałej jak Strążyska pod Giewontem. [...] Jeśli wreszcie Kościeliską Dolinę nazwano „perłą Tatr” najpiękniejszą, to Strążyska słusznie mieć winna nazwę ,perełki”25.

Niewątpliwym mistrzem, a zarazem przewodnikiem w tak pojmowanej kulturowej lekturze Tatr okazał się dla Urbanowskiej właśnie Stanisław Witkiewicz, a wzorem - jego opisy wierchów i dolin tatrzańskich, prezentowane w dziele Na przełęczy. W perspektywie turysty zbliżającego się do doliny Kościeliskiej jawi się ona jako „wspaniała nawa gotyckiej katedry, której podłogą jest ruchomy kryształ potoku”26, „w górnej swej części dolina się rozszerza, otwierając dalsze i obszerniejsze widoki; z boków jej, jak kaplice, otwierają się bramy wąwozów, naw bocznych”27, ,w głębi doliny Strążyńskiej, jak ołtarz, świeci w słońcu stroma turnia Giewontu”28, „charakter gotycki, mniej lub więcej silnie zaznaczony, noszą wszystkie prawie wąwozy, mające ujście w dolinie Zakopanego"29. Drogą do pogłębionej percepcji natury okazuje się więc w znacznej mierze kulturowa erudycja i wrażliwość obserwatora. Piękno natury postrzega i opisuje „człowiek kultury”, odkrywający w „,naturalnym” krajobrazie tatrzańskim swoisty porządek, przyswojony przez siebie wcześniej w procesie percepcji dzieł sztuki stworzonych przez znanych artystów. Nie zawsze ten model odbioru musi polegać na stosunkowo

24 J. Kolbuszewski, Wstęp, [w:] Tatry i górale w literaturze polskiej. Antologia, oprac. J. Kolbuszewski, Wrocław 1992, s. 10.

25 Z. Urbanowska, op. cit., s. 491.

26 S. Witkiewicz, Na przełęczy. Wrażenia i obrazy z Tatr, Warszawa 1891, s. 59.

27 Ibidem, s. 60.

28 Ibidem, s. 61.

29 Ibidem, s. 60. 
łatwym i prostym kojarzeniu obiektów usytuowanych w przestrzeni (na przykład turni o charakterystycznych kształtach) z formami artystycznymi - egzemplifikowanymi przez dzieła sztuki czy, jak w przytoczonym przykładzie, architektury realizującej styl gotycki. Czynnikiem stymulującym swoisty ruch wyobraźni, towarzyszącym zwiedzaniu Tatr, mogą się też okazać tradycyjne przekazy słowne, a także obrazy wykreowane przez wielkich mistrzów literatury pięknej. W mglisty dzień widok z Krzyżnego w stronę Doliny Pięciu Stawów wywołać więc może u doświadczonych turystów skojarzenie z Księgą Genesis i innymi mitami kosmogonicznymi, opisującymi stworzenie świata: „Są tacy, którzy wiele po Tatrach chodząc, mówili, że »mieli wspaniałe chwile przypominające stworzenie świata, a mianowicie: odłączenie wody od lądów i światła od ciemności«"30 — opowiada uczestnikom wycieczki do Morskiego Oka jej „nieformalny przewodnik” Jakub, antycypując niejako mające nastąpić ekscytujące doświadczenie turystów; za chwilę wszyscy staną się świadkami opisywanego w przytoczonym wspomnieniu swoistego cudu natury:

Nad nimi był błękit jasny, czysty i słońce w całym blasku promieni, a dookoła, jak daleko okiem zasięgnąć, na wszystkie strony — białe, równe, nieprzejrzane morze mgły. Ani śladu dolin lub gór, tylko z morza tego sterczały granitowe szczyty, niby wyspy wynurzające się z głębi fal. [...] Możemy sobie powiedzieć [konstatuje sir Edward], że i my przeżyliśmy taką chwilę jak przy stworzeniu świata! ${ }^{31}$

Tatrzańskie widoki mogą także wywoływać jeszcze inne asocjacje, nacechowane poczuciem eschatologicznej grozy — wedle słów protagonistów „straszne i przepyszne zarazem". W deszczowy dzień Dolina Roztoki budzi więc w bohaterach skojarzenia wręcz infernalne:

Pogruchotane ogromne urwiska [...] połamane drzewa, szalone podskoki i kamienisty łomot płynących w dół potoków, wszystko dawało miejscowości tej pozór wejścia do piekieł i Warburton odezwał się, że tak chyba będzie wyglądała ziemia w dzień sądu ostatecznego ${ }^{32}$.

Zgodnie z deklarowaną przez Urbanowską intencją zaprezentowania odbiorcy pełnego, syntetycznego obrazu Tatr w polu obserwacji protagonistów powieści pojawiają się też obszary „kulturowo zagospodarowane”: chaty i szałasy pasterskie, jak również swoiste artefakty wytworzone przez górali, towarzyszące im w życiu codziennym. Charakterystyczne wydaje się, że one także nierzadko postrzegane są przez pryzmat wcześniejszych kulturowych i literackich doświadczeń bohaterów. Wnętrze szałasu na Starej Polanie ze starymi drewnianymi naczyniami na mleko, oryginalnym łyżnikiem, pięknymi czerpakami i olbrzymim, wiszącym nad ogniskiem kotkem oraz — jak czytamy w tym literackim opisie — ,potworną warzę-

\footnotetext{
30 Z. Urbanowska, op. cit., s. 364.

31 Ibidem, s. 365.

32 Ibidem, s. 422.
} 
chą" przypomina baronetowi Edwardowi scenę czarownic z Makbeta, natomiast malarzowi Witoldowi nasuwa na myśl zasłyszaną kiedyś refleksję Witkiewicza o podobieństwie tego przedmiotu do łyżki czarownic z Balladyny. Skojarzenie z dziełami Szekspira i Słowackiego niewątpliwie w intencji autorskiej nobilituje sferę zwykłych przedmiotów pełniących w góralskiej codzienności funkcje użytkowe, przenosząc te pozornie jedynie „etnograficzne obiekty” w obszar autentycznej sztuki i przyznając im walor „wytwornego piękna”33. Podobną funkcję „dowartościowania” Tatr i góralszczyzny pełnią częste w strukturze narracyjnej powieści cytaty z dzieł literackich (już na początku utworu pojawi się więc w całości! — znany wiersz Tetmajera List Hanusi, potraktowany jako swoisty dowód językowej sprawności dialektu podhalańskiego, zdolnego wyrazić najsubtelniejsze, a zarazem uniwersalne uczucia ${ }^{34}$ ), pojawiają się nawiązania do twórczości Dantego: „Od chwili gdy przeszliśmy Żółtą Turnię [powiada Wartburton] zdaje mi się ciągle, że czytamy nowy a nieznany rozdział Boskiej komedii i że lada chwila ujrzę zstępujące w przepaście ze szczytów postacie Wergilego i Danta"35; zastanawiających ech opisu dantejskiego piekła dopatruje się też jeden z bohaterów w relacjonowanym przez siebie kazaniu księdza Stolarczyka ${ }^{36}$. Wrażliwemu erudycie Jakubowi w trakcie swoistego czytania krajobrazu widok doliny Pięciu Stawów nasuwa skojarzenie ze słynnym, przytoczonym in extenso wierszem Tetmajera Melodia mgieł nocnych (Nad Czarnym Stawem Gasienicowym), który „wypowiedziany [przez bohatera — J.Ł.] głosem poważnym i przejmującym, wywołał w słuchaczach odpowiedni nastrój" ${ }^{37}$. Istotną rolę w procesie tworzenia powieściowych znaczeń, wkomponowanych w system bliskich autorowi wartości, odgrywają też metateksty będące dla odbiorcy swoistą sugestią interpretacyjną: wszystkie rozdziały powieści poprzedzają więc motta zaczerpnięte z twórczości najwybitniejszych czy choćby tylko najbardziej popularnych polskich poetów urzeczonych Tatrami: Mickiewicza, Goszczyńskiego, Asnyka, Faleńskiego, Pola, Deotymy i Krakowowej. Kreowane na kartach powieści „obrazy Tatr” podlegają zatem, dzięki podejmowanym przez pisarkę zabiegom „równania” do kultury symbolicznej, wysokiej (uniwersalnej), swoistej idealizacji, czasem mityzacji. „Zwykłe” czynności wykonywane w świętej przestrzeni Tatr okazują się więc, przy zastosowaniu odpowiedniego klucza interpretacyjnego, swoistym rytuałem, tajemniczym obrzędem celebrowanym przez rdzennych mieszkańców tej ziemi. Znakomitym tego przykładem wydaje się niezwykle szczegółowy, pełen „technicznych” detali opis wyrobu sera, którego świadkami stają się uczestnicy relacjonowanej wycieczki do Morskiego Oka. Niezbędne wydaje się w tym miejscu przypomnienie, że opis ten jest w istocie „,kryptocytatem” zaczerpnię-

33 Ibidem, s. 403.

34 Zob. ibidem, s. 14-15.

35 Ibidem, s. 416.

36 Por. „Było coś dantejskiego w tym opisie ostatniej wędrówki [w kazaniu ks. Stolarczyka J.Ł.], choć Danta nigdy nie czytał proboszcz zakopiański” — ibidem, s. 339.

37 Ibidem, s. 345. 
tym z wzorcowego dla Urbanowskiej dzieła Witkiewicza. Interesująco i nieco zagadkowo wspomina o tym sama pisarka w cytowanym już liście do autora $\mathrm{Na}$ przełęczy, przyznając, że opisywanego w swej powieści szałasu ani relacjonowanych czynności wykonywanych przez pasterzy przy dojeniu owiec nie miała okazji zobaczyć „na własne oczy” i zna je niejako „z drugiej ręki” — z rozpraw etnografów i ludoznawców. Broniąc przy tym zastosowanej przez siebie techniki korzystania ze źródła, stwierdza: „Opisu tego z książki Pana p o ż y c z y $ł$ a m tylko na czas krótki i nie zabieram go bynajmniej na własność — a w innych ustępach przytaczam zawsze, że »pan Witkiewicz tak mówi«"38, sugerując możliwość przeredagowania tego fragmentu (,rozdział ten zupełnie przerobię"39) w bliżej nieokreślonej przyszłości.

Warto może przypomnieć w tym miejscu wzmiankowany przez Urbanowską w cytowanym liście opis sporządzony przez Witkiewicza, zestawiając go z jedną ze scen przedstawionych w Róży bez kolców:

Gielety napełnione mlekiem przynieśli [juhasi - J.Ł.] do szałasu i przez płachtę, nakrytą gałązką smreczyny, przecedził je baca do przeciery, wielkiej stągwi, do której wlał też klag, t.j. wygotowany cielęcy żołądek. [...] Po chwili baca zakasał ręce obrosłe długim włosem, obmył je, usiadł na stołku, okraczył nogami pucierę, i w milczeniu zanurzył ręce w białą ciecz mleczną. Przed nim stał zgrabny, młody chłopak, trzymając za dwa rogi płachtę, przypiętą dwoma drugiemi do jego pasa. Była to chwila uroczysta. Zdawało się, że ten stary, z łysem czołem człowiek [...] odprawia jakiś tajemniczy i religijny obrządek, a młody służy mu, jakby służył do mszy. Kto zresztą zgadnie, czy im samym ta nagła przemiana, zachodząca w mleku, bo powstawanie sera, nie przedstawia się jako zjawisko cudowne, którego przyczyny dalsze leżą poza kresem ludzkiej wiedzy ${ }^{40}$.

Wzorowany na przytoczonym opisie fragment powieści Urbanowskiej zachowuje wierność wobec literackiego „oryginału” zarówno w warstwie faktograficznej, jak i rekonstruowanej sferze kulturowych i religijnych sensów, przypisywanych pozornie banalnym zdarzeniom z życia codziennego pasterzy, wypasających swe stada na tatrzańskich halach:

Przypatrywali się, jak baca mleko z gieletów wylewał do wielkiej stągwi, cedząc przez płachtę, nakrytą gałązką smreczyny, co mu odrębny nadawało zapach; jak wlewał do niego jakiś mętny płyn, wygotowany z cielęcego żołądka, mającego własność ścinania mleka, a poczekawszy czas jakiś, obmył w wodzie ręce, obrosłe czarnym długim włosem, i zanurzył je w mleku po łokcie. Przed bacą stał młody chłopak, trzymając

\footnotetext{
38 Zofia Urbanowska do Stanistawa Witkiewicza..., s. 672.

39 Ibidem.

40 S. Witkiewicz, op. cit., s. 91.
} 
za dwa rogi płachtę, przypiętą do pasa. I on, i baca, i goście, przyglądając się tej czynności, głębokie zachowywali milczenie ${ }^{41}$.

Obserwowana przez protagonistów scena - oceniona przez Warburtona jako „niezbyt apetycznie wyglądająca” - okazuje się jednak (przy uwzględnieniu innej, bardziej refleksyjnej perspektywy i punktu widzenia) sceną świadomie uteatralizowaną, pełną znaczeń niewidocznych niejako „na pierwszy rzut oka”. Roli egzegety tego zdarzenia podejmuje się malarz Witold, powołując się przy tym, co oczywiste, po raz kolejny na autorytet Stanisława Witkiewicza:

Witkiewicz utrzymuje, że chwila, w której baca zanurza ręce w mleku, jest chwilą uroczystą. Gdy działo się to w jego obecności, wydawało mu się, że ten stary, z łysym czołem człowiek [...] odprawia jakiś tajemniczy obrządek, a młody służy mu do niego. I dodał: „Kto zgadnie, czy w nim samym ta nagła przemiana zachodząca w mleku, to powstawanie sera, nie przedstawia się jako zjawisko cudowne, którego przyczyny leżą poza kresem ludzkiej wiedzy"42.

Widoczna w partiach opisowych dzieła skłonność do idealizacji prezentowanego świata obejmuje również, co oczywiste, samych górali, „wpisanych” w pejzaż tatrzański. Zachwyt turystów zwiedzających Tatry budzi więc już typ antropologiczny, reprezentowany przez „tubylców”. Intryguje ich „portret mentalny” — inteligencja, poczucie humoru, odwaga, duma, przywiązanie do wolności; estetycznej satysfakcji dostarczają ich wrodzone zdolności artystyczne - talenty gawędziarskie, ale przede wszystkim muzyczne i taneczne ${ }^{43}$, podziw (a nawet kolekcjonerską namiętność!) wzbudza tradycyjny strój, obuwie ${ }^{44}$ i góralskie ozdoby — baronet zafascynowany mosiężną spinką u koszuli bacy, którą postrzega jako „klejnot prawdziwy”; pragnie ją nawet kupić, a spotkawszy się z odmową właściciela, prosi towarzyszącego mu malarza o wykonanie rysunku tego pięknego przedmiotu ${ }^{45}$. Istotne dowartościowanie kulturowego obrazu górala jest posłużeniem się przez Urbanowską, za Stanisławem Witkiewiczem, stosowną, mityczną genealogią najsłynniejszych rodów zakopiańskich - Gąsieniców i Walczaków, dumnych ze swego „starożytnego pochodzenia” bardziej niż ,gdzie indziej w zamkach z tytułów i herbów”46, z charakterystycznym jednak przemilczeniem przez pisarkę lapidarnie zaznaczonej przez twórcę Na przelęczy kwestii wzajemnych animozji między przedstawicielami tych najstarszych i najsłynniejszych zakopiańskich rodów ${ }^{47}$. Interesująca wydaje

41 Z. Urbanowska, op. cit., s. 412.

42 Ibidem, s. 413.

43 Por. „Góral jak posłyszy muzykę, już mu się usta nie zamykają od śpiewu, a nogi na miejscu ustać nie mogą" - ibidem, s. 338.

44 Por. „Kierpce [...] to obuwie prawdziwie klasyczne” — ibidem, s. 289.

45 Ibidem, s. 404.

46 Ibidem.

47 Por. „Arystokracya rodowa nie tylko gnieździ się w »dumnych« zamkach; ten oto, brudny »Ojciec szałasu«, odziany kudłami owczej wełny, jest tak dumny ze swego walczakostwa, jak 
się pod tym względem swoista społeczna i kulturowa konfrontacja oczekiwań przybyłej z Wileńszczyzny babuni Kasi, reprezentującej stan szlachecki, ze zwyczajami goszczących ją górali.

Szanowna pani [tłumaczy przyczynę „towarzyskich” nieporozumień zaznajomiony z miejscowymi realiami Jakub] przywykła do tego, że chłopi kłaniają się do kolan i stają u drzwi nieśmiało; ale tu są inne obyczaje, innymi stosunkami wytworzone od wieków. Tu góral nie zależy i nie zależał nigdy od dworu, więc i w zachowaniu się jego nie ma pokory, a jest natomiast swoboda, pewność siebie i szlachetna godność w obejściu ${ }^{48}$,

a w wypowiedzi tej pobrzmiewają echa opinii sformułowanej przez Witkiewicza: „Chłop ten [góral - J.Ł.] nie był niczyim poddanym. Rósł wolny i dziki, i przy wszystkich formach uniżoności zachowywał godność osobistą i hardość ducha. Szanował się i kazał siebie szanować"49.

Wykreowany na kartach Róży bez kolców obraz górala współtworzy przypisywane mu, i szczególnie przez przybyszy cenione, poczucie humoru: „Już to z dowcipu słyną tatrzańscy górale [...] jak również ze swobodnego umysłu" stwierdza jeden z protagonistów, Witold, powołując się w tym miejscu na opinię Tytusa Chałubińskiego, który „znał górali dobrze, zawsze podziwiał ten dowcip delikatny. Opowiadał on chętnie różne ich odezwania się i figle" 50 . Wydaje się godne podkreślenia, że wspomniane komponenty fizycznego i mentalnego wizerunku górala zdają się w powieści obowiązywać także w odniesieniu do bardziej kontrowersyjnych, historycznych wątków i fenomenów miejscowej tradycji, a więc do tatrzańskiego zbójnictwa. Malarz Witold, opowiadając o poczynaniach zbójników, zauważa więc, że złodziejski i rozbójniczy proceder związany był „z pewnego rodzaju dowcipem i humorem”, na dowód przytaczając anegdotę o kradzieży wołów, zgodnie z którą zbójnicy „zamiast w prostacki sposób woły zabierać", przybywają pod nieobecność karczmarza z muzyką i zapraszają jego żonę i służbę do tańca, a w czasie zabawy ostrzegają w specjalnej śpiewce o niebezpieczeństwie, jakie zagraża wołom ${ }^{51}$. Sir Warburton przytacza natomiast przeczytaną w Kartkach z podróży Wiktora Tissota, rzekomo prawdziwą, opowieść zakopiańskiego proboszcza o napaści zbójników na pewien dom, zakończoną — z powodu zdecydowanego oporu mieszkańców — wycofaniem się napastników w tanecznym korowodzie z własną muzyką na przedzie i charakterystyczną refleksją: „Nie jestże to najoryginalniejsza na świecie fantazja? Czy słyszał kto

potomek potężnych szlacheckich rodów ze swoich tytułów i dyplomów. Gąsienice też i Walczaki chowają do siebie różne, tajone lub groźnie wybuchające zawiści i wzajemną pogardę" - S. Witkiewicz, op. cit., s. 90.

48 Z. Urbanowska, op. cit., s. 53.

49 S. Witkiewicz, op. cit., s. 39.

50 Z. Urbanowska, op. cit., s. 343.

51 Ibidem, s. 342. 
co podobnego? Czy w którym kraju zbójcy kiedykolwiek napadali ze śpiewem i muzyką?"52.

Wartości poznawcze i edukacyjne, a zarazem swego rodzaju retoryczna skuteczność, jaką przypisać można Róży bez kolców, wiążą się niewątpliwie z osobliwą strategią narracyjną, stosowaną przez pisarkę, zgodnie z którą głównymi „rzecznikami” idealizacji Tatr w powieści okazują się postaci rzeczywiste, szczególnie zasłużone w procesie kształtowania się w czasach, gdy rozgrywa się akcja utworu, obecnego w społecznym dyskursie obrazu Tatr i góralszczyzny. Urbanowska, konstruując wątki i sytuacje dialogowe, łączy więc bohaterów fikcyjnych należących do świata przedstawionego z postaciami historycznymi, „streszczającymi” niejako w konkretnych kwestiach dialogowych swoje rzeczywiste, wyłożone w opublikowanych pracach naukowych i popularyzatorskich poglądy i koncepcje. Witold (malarz), Jakub (lekarz) i nastoletni Henryk — fikcyjni bohaterowie powieści - spotykają zatem w trakcie pewnej tatrzańskiej eskapady najpierw Stanisława Witkiewicza i doktora Matlakowskiego, a zaraz potem także Bronisława Dembowskiego, mając szansę wysłuchania prowadzonej przez nich dysputy o stylu zakopiańskim. W jej trakcie zapoznają się z kolekcjonerskimi pasjami miłośników sztuki ludowej, przekonują o wyższości „,rodzimego piękna” nad „zagraniczną, brzydką i oklepaną tandetą" "53. Dzięki temu doświadczeniu, a także wyjaśnieniom i komentarzom należącego do świata przedstawionego powieści rezonera Witolda nastoletni bohater otrzymuje też swoistą „lekcję poglądową": „[Henryk] po tym, co usłyszał od doktora Matlakowskiego, innymi oczyma teraz patrzył na otoczenie" 54 .

Znaczny udział w komponowaniu obszernej i wieloaspektowej ,syntezy Tatr” (będącej, jak już zostało wspomniane, zasadniczym celem autorki) bohaterów, mających swe autentyczne pierwowzory w postaci konkretnych osób, znanych i popularnych zarówno ,pod Giewontem”, jak i w całej Polsce, ma swe najbardziej prawdopodobne źródło w wyznawanym przez Urbanowską pozytywistycznym kulcie wiedzy oraz w uznaniu dla autorytetu uczonych. Mówić można jednak, jak się zdaje, o innych jeszcze motywacjach tego stanu rzeczy. W kontekście rozważań o idealizacji nasuwa się przypuszczenie, że wzorowani na postaciach rzeczywistych, zasłużonych dla popularyzacji wiedzy o Tatrach, powieściowi bohaterowie-rezonerzy zdejmują niejako z narratora odpowiedzialność za przyjętą postawę, polegającą na gloryfikacji elementów przedstawianej rzeczywistości, dostosowywania ich do idealnych wyobrażeń. W przyjętej perspektywie komunikacyjnej okazuje się on osobą „referującą” (jedynie?) poglądy autorytetów, „samoograniczając się" niejako w korzystaniu z tradycyjnych kompetencji typowego dla modelu powieści pozytywistycznej narratora wszechwiedzącego. Obserwację tę potwierdza, analizując relacje między narracją odautorską a wypowiedziami postaci działających, Barbara Kosmowska:

\footnotetext{
52 Ibidem, s. 338 .

53 Ibidem, s. 277.

54 Ibidem, s. 283.
} 
w najpóźniej powstałej Róży bez kolców narrator [...] zachowuje swą „pisarską anonimowość”. [...] W powieści tatrzańskiej Urbanowska zarzuca niemal całkowicie metodę obrazowania przy pomocy wszechwiedzy narratora, powierzając tę czynność bohaterowi ${ }^{55}$.

To właśnie powieściowi protagoniści, realizując przewidziane dla siebie w strukturze narracji funkcje dialogowe (niekiedy nawet $\mathrm{z}$ odpowiednio dozowanymi elementami polemiki), stwarzają narratorowi możliwość skupienia się na referowaniu opinii znawców, a nawet — przez odpowiednie zestawianie i konfrontowanie stanowisk prezentowanych przez rozmówców — zachowania pewnego rodzaju poznawczego dystansu wobec przekazywanych treści. We wspomnianej wcześniej rozmowie o stylu zakopiańskim i pięknie tatrzańskiej przyrody, prowadzonej przez Witkiewicza i Matlakowskiego jako replika dialogowa, pada więc charakterystyczna, ironiczno-dystansująca fraza: „pan jesteś poetą" ${ }^{56}$, przypominająca słynną kwestię Racheli z Wesela Wyspiańskiego. Odnosi się ona jednak w tym kontekście raczej do nasyconej emocjami „formy”, nie zaś do „treści" tak spointowanej wypowiedzi; obaj interlokutorzy - wielbiciele i znawcy Tatr — nie bez powodu już w tytule jednego z rozdziałów Róży bez kolców określeni zostali właśnie mianem „poetów”, obdarzonych szczególną wrażliwością i intuicją. Miejscem ujawniania się kompetencji głównego podmiotu mówiącego, a zarazem ważnym „dowodem jego wszechwiedzy” są natomiast wspomniane przez Kosmowską zdania uogólniające ${ }^{57}$. Przyjmują one czasem formę „uwag na stronie", w których pisarka wyraża poznawczy i emocjonalny (choć niekoniecznie polemiczny) dystans wobec „cytowanych” wypowiedzi, a także wobec określonych poczynań postaci działających. Niekiedy te uwagi i komentarze związane są z rekonstrukcją punktu widzenia postaci mówiącej, określonego jej profesją, wyznawanym systemem wartości i sposobem widzenia świata. Tworząc postać towarzyszącego Warburtonowi przyrodnika, ekscentrycznego profesora Stranda, i śledząc jego perypetie będące konsekwencją połączenia bezkompromisowego umiłowania wiedzy z nieprzezwyciężoną niechęcią do kobiet, nie bez powodu aktualizuje przecież pisarka stereotypowe wyobrażenia związane z przedstawicielami świata nauki, pozwalając sobie nawet na pewien odcień ironii, widoczny w sformułowanej przez narratora obserwacji: ,ale nasz uczony, wzorem wszystkich uczonych, nie widział nic prócz tego, co chciał widzieć, a czego na próżno upatrywał od kilku godzin"58.

Autorka, tworząc szczegółowo przez siebie zaplanowaną, ,zbeletryzowaną encyklopedię Tatr", stara się więc zachować swoistą równowagę między syntetyzującym spojrzeniem epika czuwającego nad właściwym rozłożeniem akcentów i kompletnością wykreowanego obrazu a merytoryczną i ideową zawartością

55 B. Kosmowska, op. cit., s. 102.
56 Z. Urbanowska, op. cit., s. 281.
57 B. Kosmowska, op. cit., s. 103.
58 Z. Urbanowska, op. cit., s. 455. 
wypowiedzi bohaterów — znawców rzeczywistości tatrzańskiej — „odpowiadających" za kompetentne nauczanie młodego czytelnika geografii Tatr, ich historii, a także etnografii i folkloru Podhala, którym to protagonistom-rezonerom przypisana została również funkcja dzielenia się z odbiorcą swymi turystycznymi pasjami i zachwytem nad urodą tych gór.

\section{Bibliografia}

Hoesick F., Legendowe postacie zakopiańskie. Chałubiński, ks. Stolarczyk, Sabała, Warszawa 1922. Jazowska-Gomulska M., Antropologiczna koncepcja kultury w Róży bez kolców Zofii Urbanowskiej, [w:] eadem, Oswajanie z kultura. W kręgu inspiracji folklorystycznych w literaturze dla dzieci i młodzieży, Kraków 2001.

Jazowska-Gomulska M., Róża bez kolców. Dzieje wydawnicze powieści, „Annales Universitatis Paedagogicae Cracoviensis" 8, 2010.

Kolbuszewski J., Tatry w literaturze polskiej, cz. 1-2, Kraków 1982.

Kolbuszewski J., Wstęp, [w:] Tatry i górale w literaturze polskiej. Antologia, oprac. J. Kolbuszewski, Wrocław 1992.

Kosmowska B., Pomiędzy dzieciństwem a dorosłością. O powieściopisarstwie Zofii Urbanowskiej, Słupsk 2003.

Kuleczka P., Tatry w literaturze polskiej dla dzieci i młodzieży do roku 1939, Zielona Góra 1994.

Lewiński P., Retoryka reklamy, Wrocław 1999.

Listy o stylu zakopiańskim 1892-1912. Wokół Stanisława Witkiewicza, oprac. M. Jagiełł, Kraków 1979.

Nowińska E., Prawo reklamy, [w:] K. Janiszewska et al., Wiedza o reklamie. Od pomystu do efektu, Bielsko-Biała 2009.

Urbanowska Z., Róża bez kolców, Warszawa 1980.

Witkiewicz S., Na przełęczy. Wrażenia i obrazy z Tatr, Warszawa 1891.

Zofia Urbanowska do Stanisława Witkiewicza, list z dnia 15 czerwca 1901 roku, [w:] Listy o stylu zakopiańskim 1892-1912. Wokót Stanisława Witkiewicza, oprac. M. Jagiełło, Kraków 1979. 